\title{
Population and nesting records of House Sparrow Passer domesticus in Yellampet, Nizamabad District, Telangana, India
}

\author{
Buddi Laxmi Narayana \\ Department of Wildlife Biology, A.V.C. College (Autonomous), Mannampandal, Mayiladuthurai, \\ Tamil Nadu. \\ All India Network Project on Vertebrate Pest Management, Prof. Jayashakar Telangana State \\ Agricultural University, Rajendranagar, Hyderbad-500030 \\ ${ }^{*}$ Corresponding author e-mail: narayna.laxmi@gmail.com
}

Key words: Agriculture, ecological density, House Sparrow, India, nesting.

\begin{abstract}
Studied the population and nesting records of House Sparrow Passer domesticus during winter in Yellampet village, Telangana. The ecological density of House Sparrow was investigated using fixed width transects. The density of sparrow vary from 15 to 335 per hectare in different transects. Bonferroni confidence interval was used to know the preference of location types i.e., houses, shops and hotels for foraging and nesting. Shops were used significantly more than expected according to availability of nest sites and also for foraging. A total of 81 active nests were recorded. The present study shows that a handful breeding population of House Sparrow harboring in Yellampet village.
\end{abstract}

\section{INTRODUCTION}

Most commonly used indicators for ecological monitoring are birds, as they are sensitive to even small environmental changes and thus useful models for studying a variety of environmental problems [1]. The House Sparrow Passer domesticus is one such species, which is known to cooccur with humans from historic times, and thus serves as a good indicator of the ecological quality [2]. The House Sparrow is highly adaptable to urban, suburban and agricultural habitats [3]. In India, the distribution of House Sparrow is widespread. And once, House Sparrow was one of the commonest urban birds in India [4]. It was so numerous in towns and cities of Europe that it was regarded as a pest in many parts of Europe [5]. But recent studies show that there is dramatic decline of the species in many parts of the world. Since mid 1970 's $47 \%$ of rural and $60 \%$ of the urban and sub urban population has declined in U.K. [6]. As a result the species is included in the Red list of species of Conservation Concern [7]. The population decline of this species is also reported throughout North-Western Europe $[8,9,10]$. Hence, House Sparrow is now listed in a Species of European Conservation Concern (SEPC category 3; Bird life international 2006 [11,12]. Though quite a few hypotheses are put forward to enlighten the declination of the species viz., reduction in food supply, increasing developmental activities, reduced availability of nest sites, and electromagnetic radiation, but there is no strong evidence to support any of these $[13,14,15,16]$. Decline in sparrow population also reported from India [4], but there is no authentic historical data on the species, to compare the population trend [17]. However, made an effort to record the population of House Sparrow in Andhra Pradesh, Delhi, Bangalore and Tamil Nadu [17,18,19,20]. The present study is aimed to record the population and active nests of House Sparrow in Yellampet village of Telangana.

\section{MATERIAALS AND METHODS}

\section{Study Area}

The survey was carried out in Yellampet village $\left(18^{\circ} 24.209^{\prime} \mathrm{N}\right.$ to $\left.78^{\circ} 29.855^{\prime} \mathrm{E}\right)$, Nizamabad District of Telangana (Fig.1). Agriculture is the backbone of this village which grows paddy, sugarcane, maize, turmeric, cotton, groundnut, sunflower and pulses. The total area of village is 
near about $25 \mathrm{sq} . \mathrm{km}$. In winter temperature ranges from $10^{\circ} \mathrm{C}$ to $20^{\circ} \mathrm{C}$ and in summer it goes up to $47^{\circ} \mathrm{C}$. Scarcity of water is mainly fulfilled by the number of irrigation systems such as Nizamsagar, Sree Ram Sagar, Pocharam, Ramadugu and Nallavagu. The total population of Yellampet village is 2623 in 408 households. Majority of farmer of this village are belonging to tribal community called Lambadis. Their Houses mostly made up woods, straws and tin sheets and almost all houses are similar in size and structure. Apart from that cattle's are one of the livelihood options with agriculture of the village people.

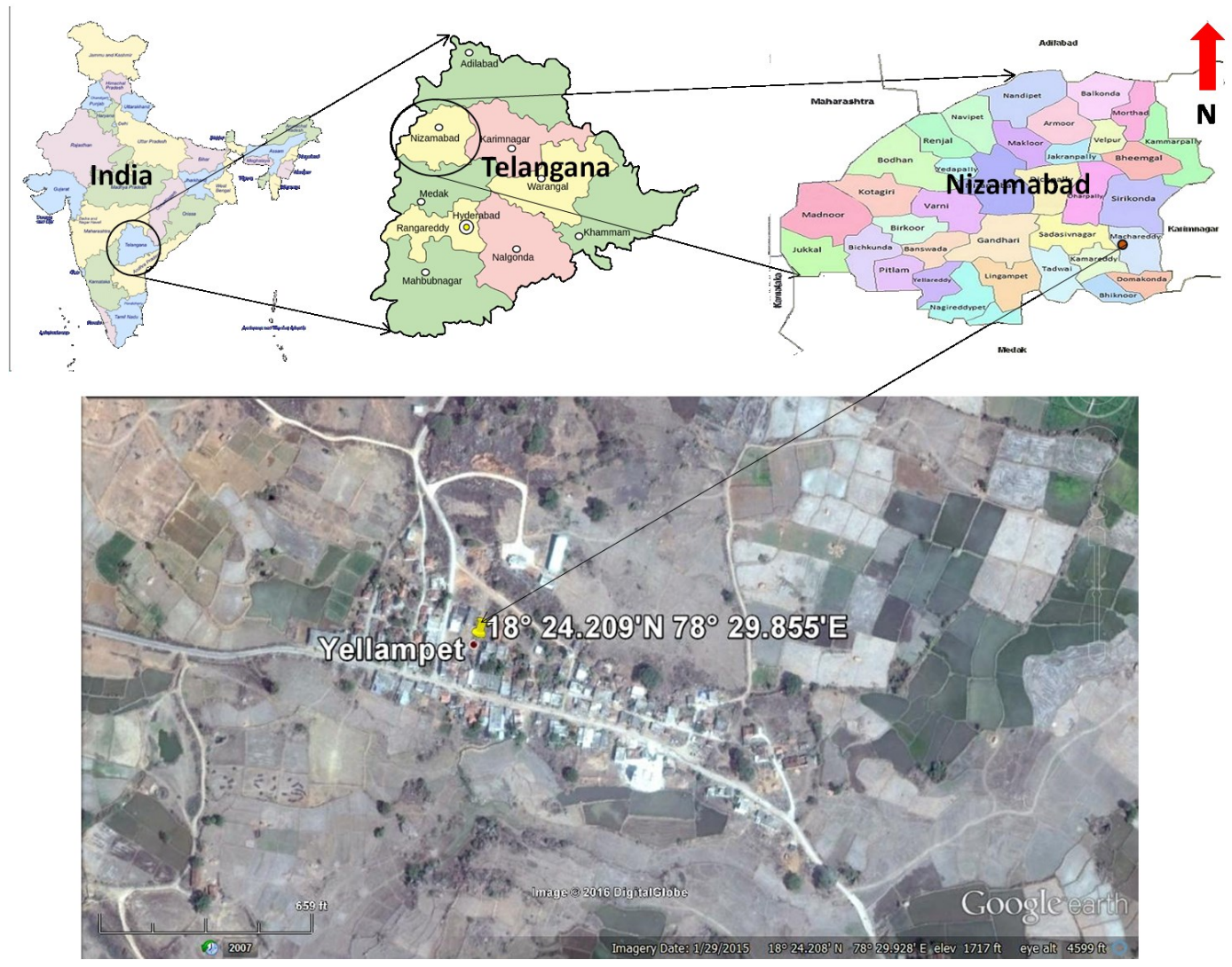

Fig 1: Study area map

\section{Methods}

The bird survey was carried out in winter during December 2010 to January 2011. We laid 20 fixed width transects each of $50 \mathrm{~m}$ length $20 \mathrm{~m}$ width at either site randomly in different parts of the human habitation present in the study area. Transects were surveyed on foot in the morning between 0600-0900 hrs. In total, 20 transects comprised of 94 residential houses, 11 shops and six hotels. The number of individuals and active nests of House Sparrow was recorded separately for houses, shops and hotels. Apart from that the sparrows foraging on road sides were also taken in to account. Bonferroni confidence interval was used for the preference of location types. A statistical method for calculating simultaneous confidence intervals for use with utilization-availability data $[21,22]$. The chi-square test was used to initially determine whether there is a significant difference between the expected utilization of habitat types (based on frequency of availability) and the observed frequency of usage [22]. If the chi-square test indicates a statistically significant difference between expected and observed usage, Bonferroni confidence intervals can then be used to determine which habitat type(s) are being preferred. [21,22] both used the availability of data in terms of area and the number of individuals encountered in each area. But in this study we modified and the data for habitat use was collected in terms of frequency of location type (i.e., house, shop and hotel). We counted the number of houses, shops and hotels and respective number of House Sparrow and its nest present in each of the locations and then fit into the Bonferroni confidence intervals. 


\section{RESULTS}

A total of 539 House Sparrows were encountered in 20 transects (Photo $1 \& 2$ ). The density of House Sparrow vary from 15 to 335 per hectare in different transects (Fig.2 \& 3). The mean density of House Sparrow was recorded $134.75 \pm 24.65$ SE per hectare. In human habitation, 207 birds were found to be associated with houses, 154 with road sides (sand roads), 129 with Shops and 48 with hotels. A total of 81 active nests were recorded. Among these, 56 nests in houses, 21 in shops and 4 in hotels (Fig.4). The number of individuals (Chi-squared: $\chi^{2}=296.06, d f=2, p<0.001$ ) and number of nests (Chi-squared: $\chi^{2}=23.31, d f=2, p<0.001$ ) significantly vary among the location types according to the availability of the habitat. The Shops were used significantly more than expected according to availability. On the other hand houses and hotels were used less compared to shops during morning (Table.1). And also shops were used significantly more than expected according to availability of nest sites (Table.2).

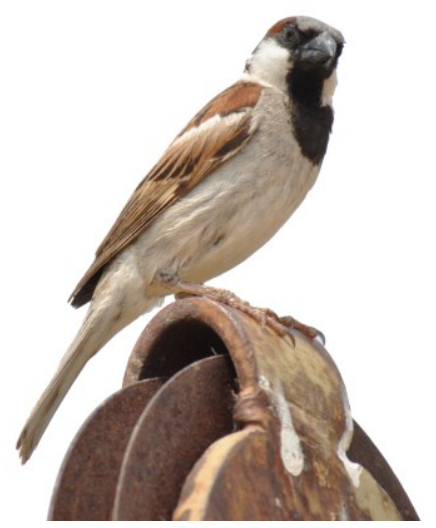

Photo 1: Passer domesticus (Male).

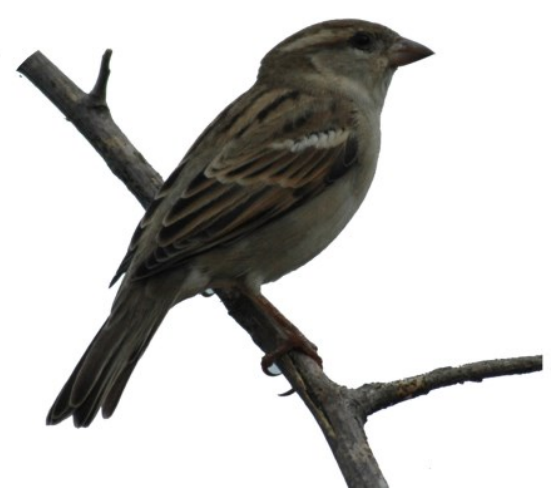

Photo 2: Passer domesticus (Female).

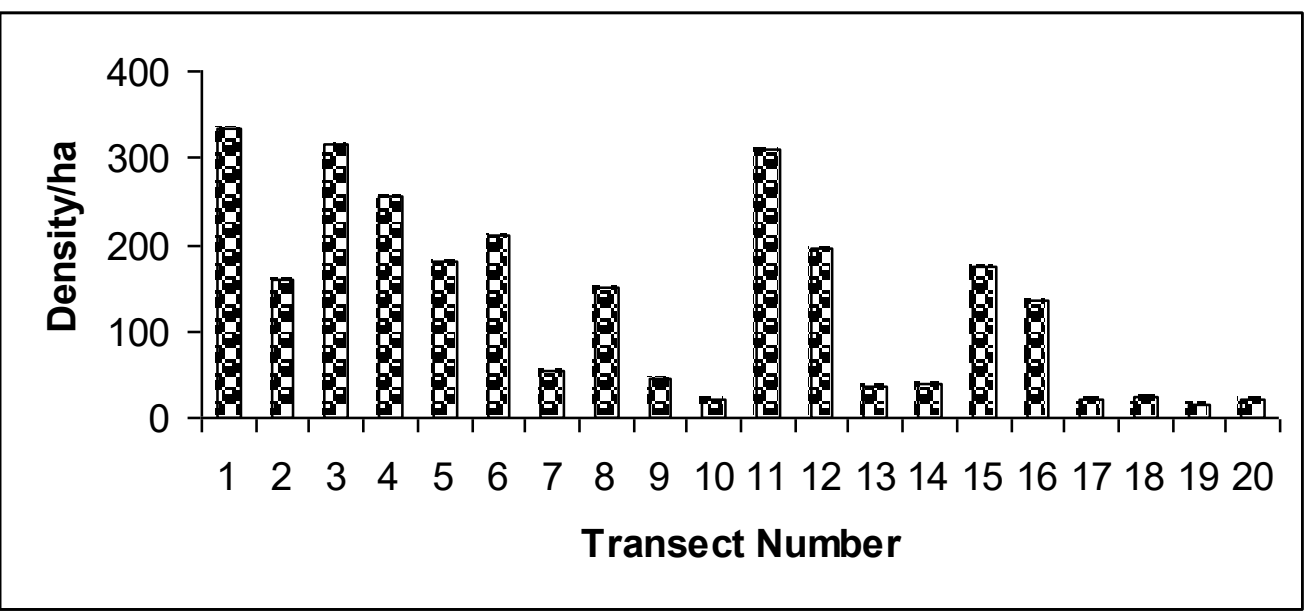

Fig 2: Variations in the density of House Sparrow in different transects of Yellampet village during December 2010 to January 2011 


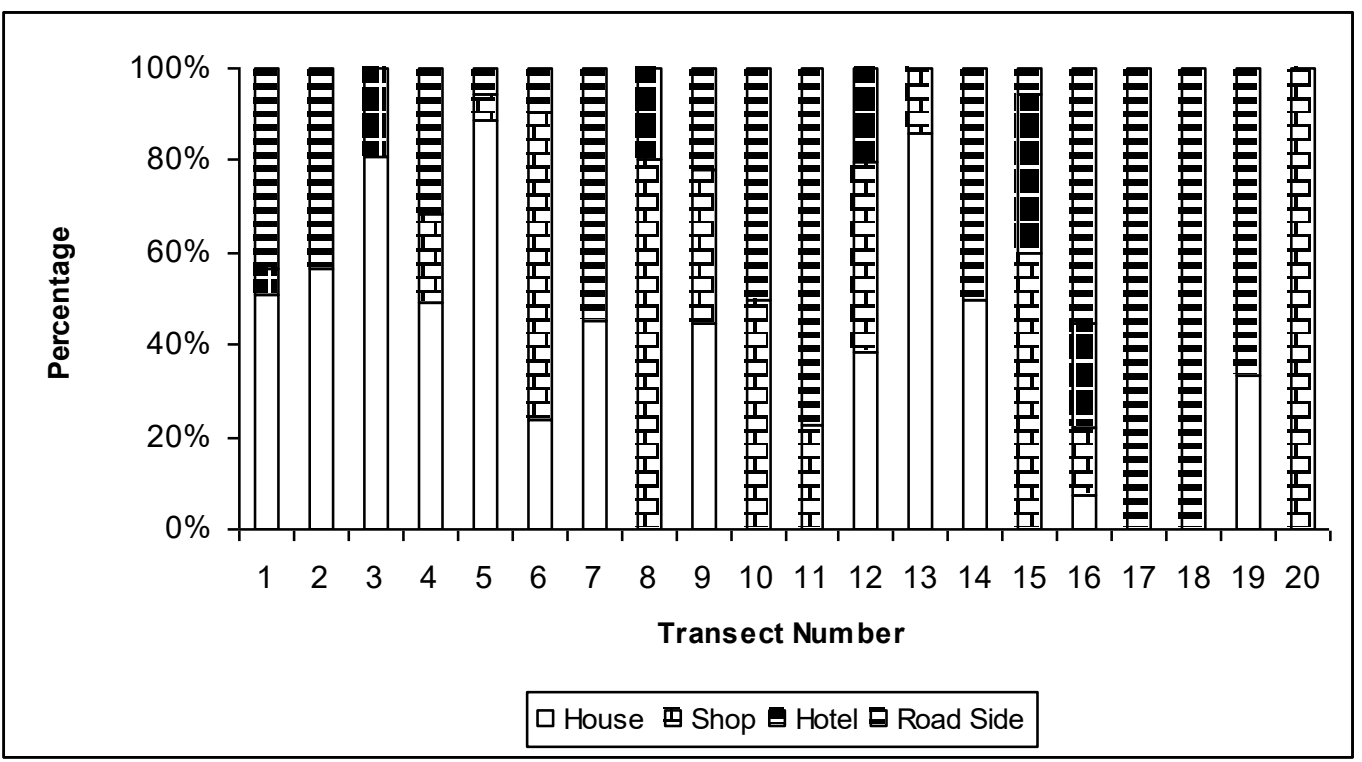

Fig 3: Percentage of House Sparrows recorded in houses, shops, hotels and road sides Yellampet village during December 2010 to January 2011

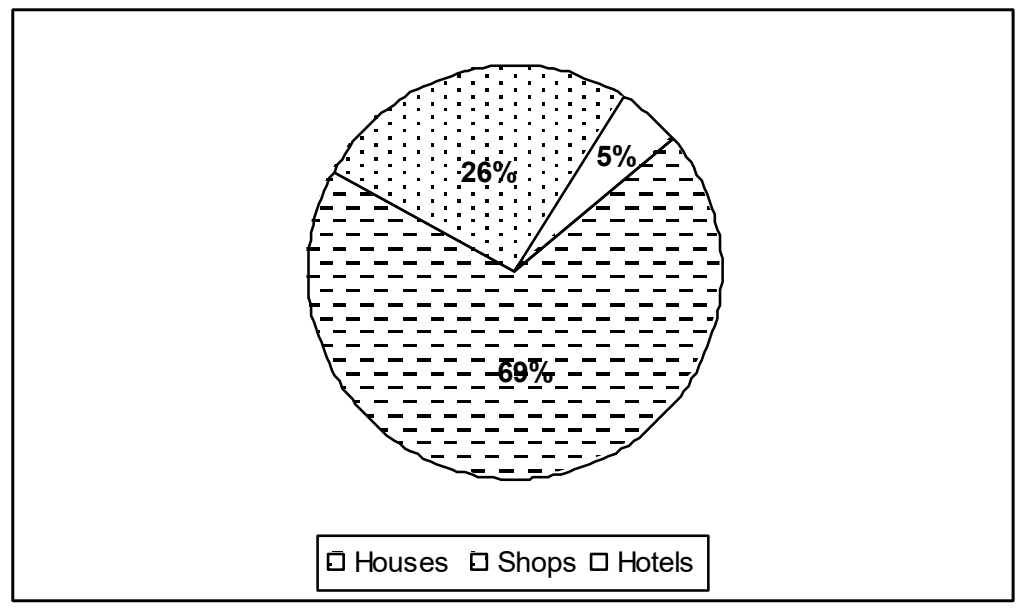

Fig 4: Percentage of active nests found in houses, shops and hotels of Yellampet village during December 2010 to January 2011

Table 1: Occurrence of House Sparrow on houses, shops and hotels in Yellampet village in winter morning, during December 2010 to January 2011.

\begin{tabular}{|c|c|c|c|c|c|c|}
\hline $\begin{array}{l}\text { Location } \\
\text { type }\end{array}$ & $\begin{array}{c}\text { Total } \\
\text { no. each } \\
\text { type }\end{array}$ & $\begin{array}{l}\text { Proportion } \\
\text { of total } \\
\text { no. each } \\
\text { type }\end{array}$ & $\begin{array}{l}\text { No. of } \\
\text { House } \\
\text { Sparrow } \\
\text { observed }\end{array}$ & $\begin{array}{c}\text { Expected no. } \\
\text { of House } \\
\text { Sparrow } \\
\text { observed }\end{array}$ & $\begin{array}{l}\text { Proportion of } \\
\text { House } \\
\text { Sparrow } \\
\text { observed in } \\
\text { each location } \\
\text { type (pi) }\end{array}$ & $\begin{array}{l}\text { Confidence } \\
\text { interval on } \\
\text { proportion of } \\
\text { occurrence at } \\
a=0.001\end{array}$ \\
\hline House & 94 & 0.846 & 207 & 325.189 & 0.539 & $0.447 \leq p 1 \leq 0.630$ \\
\hline Shop & 11 & 0.099 & 129 & 38.054 & 0.335 & $0.249 \leq p 2 \leq 0.422 *$ \\
\hline Hotel & 6 & 0.054 & 48 & 20.756 & 0.125 & $0.064 \leq p 3 \leq 0.185$ \\
\hline Total & 111 & 1 & 384 & 384 & 1 & \\
\hline
\end{tabular}


Table 2: Presence of House Sparrow nest on houses, shops and hotels in Yellampet village in winter during December 2010 to January 2011.

\begin{tabular}{|c|c|c|c|c|c|c|}
\hline $\begin{array}{l}\text { Location } \\
\text { type }\end{array}$ & $\begin{array}{l}\text { Total } \\
\text { no. } \\
\text { each } \\
\text { type }\end{array}$ & $\begin{array}{l}\text { Proportion } \\
\text { of total } \\
\text { no. each } \\
\text { type }\end{array}$ & $\begin{array}{c}\text { No. of } \\
\text { House } \\
\text { Sparrow } \\
\text { nest } \\
\text { observed }\end{array}$ & $\begin{array}{l}\text { Expected no. } \\
\text { of House } \\
\text { Sparrow nest } \\
\text { observed }\end{array}$ & $\begin{array}{l}\text { Proportion of } \\
\text { House Sparrow } \\
\text { nest observed } \\
\text { in each } \\
\text { location type } \\
\text { (pi) }\end{array}$ & $\begin{array}{l}\text { Confidence } \\
\text { interval on } \\
\text { proportion of } \\
\text { occurrence at } \\
\quad a=0.001\end{array}$ \\
\hline House & 94 & 0.846 & 56 & 68.594 & 0.691 & $0.541 \leq p 1 \leq 0.718$ \\
\hline Shop & 11 & 0.099 & 21 & 8.027 & 0.259 & $0.331 \leq p 2 \leq 0.512 *$ \\
\hline Hotel & 6 & 0.054 & 4 & 4.378 & 0.049 & $0.114 \leq p 3 \leq 10.256$ \\
\hline Total & 111 & 1 & 81 & 81 & 1 & \\
\hline
\end{tabular}

Chi-squared: $\chi^{2}=\mathbf{2 3 . 3 1}, \boldsymbol{d f}=\mathbf{2}, \boldsymbol{p}<\mathbf{0 . 0 0 1}, *$ Indicates location type used more than expected according to availability

\section{DISCUSSION}

The study shows that the House Sparrows are harboring in Yellampet village. The density of House Sparrow was found to be congested during morning in houses and shops. As after awakening from roost, they forage in flocks, in and out of residential houses and shops. The presence of granary in houses made an extra food source to sparrows. Therefore, the density can be depicted as ecological density which is always higher than that of the crude density. Ecological density includes only that portion of land that can actually be colonized by the species whereas crude density includes all the land within the organism's range [23]. [6] Found that the highest densities of House Sparrows occurred in suburban and rural housing, although there was a wide variation depending on region. On the other hand, agricultural area provides plenty of food in the form of food grains and insects [24]. The preference towards the shops is directly related to the fallen grains and other food staffs present in shops. The overall population of UK House Sparrows is estimated to have declined from approximately 13 million pairs in the early 1970s to around 6 million pairs by the late 1990s [25,6]. There is evidence that declines vary both geographically and according to habitat. [26] Showed that declines are occurring in most urbanised parts of England, whereas in Scotland and Wales, populations are increasing.

[12] Suggesting that the present distribution of House Sparrows in many urban areas is linked to human socioeconomic status, and consider potential mechanisms to explain a possible link between House Sparrow populations and social deprivation. They focus on three ways in which socioeconomic status could influence House Sparrow populations: by creating differences in habitat structure which may impact upon foraging success; by causing indirect effects such as increased predation risk; and potential effects on nest site availability. In the present study we found 81 active nests of House Sparrow, which attributes that the sparrows are successfully breeding in the village. Here also shops were preferred more according to the availability. One of the reasons may be presence of food resource was high as most of them are grocery shops in the market. And the predation pressure will be less compared to the residential houses, since presence of domestic animals like cat will be less in shops compare to residential houses and [4] also reported that domestic cats and crows destroy eggs and nestlings of sparrows. Hence, the present study shows that the handful population of House Sparrow still glowing in a small village from Telangana. Attempting to bring back the House Sparrow to cities may prove incompetent. It is wiser to conserve the sparrow in suburban, agricultural and hill landscapes, where it is still common [4]. This study has done during winter season. Therefore long term study is needed to understand the variations in density of sparrows. Hence, monitoring of sparrow population can be helpful to understand the change in surrounding environment. 


\section{ACKNOWLEDGEMENT}

I would like to thank Mr. Anukul Nath and Mr. A. Kalaimani (A.V.C College, Depart. of Wildlife Biology) for providing various information and references during manuscript preparation. Finally I would also like to thank Mr. G. Baburao and Mr. B. Naresh (students of A.V.C College) for their continuous encourage during the study period.

\section{REFERENCES}

[1] I. Newton. The contribution of some recent research on birds to ecological understanding. Journal of Animal Ecology. 64 (1995) 675-696.

[2] N. Kheera, A. Das, S. Srivastava, and Jain, S. 2009. Habitat-wise distribution of the House Sparrow (Passer domesticus) in Delhi, India. Urban Ecosystem, 13 (2009) 147-153.

[3] S. Ali, and Ripley, S. D. Handbook of the Birds of India and Pakistan (comp. Edn), Oxford University Press, New Delhi. (1983) pp. 669-673.

[4] R.J.R. Daniels. Can we Save the Sparrow?. Current Science, 95(11) (2008) 1527-1528.

[5] H.Q.P. Crick, R.A. Robinson, G.F. Appleton, N.A. Clark, and Rickard, A.D. Investigation into the causes of the decline of Starlings and House Sparrows in Great Britain. British Trust for Ornithology (BTO), Thetford (2002).

[6] R.A. Robinson, G.M. Siriwardena, and Crick, H.Q.P. Size and trends of the House Sparrow Passer domesticus population in Great Britain. Ibis, (2005) 147:552-562.

[7] R.D. Gregory, M.A. Eaton, D.G. Noble, G, Robinson, M. Parsons, H. Baker, G. Austin, G. and Hilton, M.A. The state of the UK's birds 2002. The state Birds of RSPB/BTO/WWT/JNCC, Sandy, UK. (2003).

[8] A. Prowse. The urban decline of the house sparrow. British Birds, 95 (2002)143-146.

[9] R. Mulsow. Hamburg. In: Kelcey JG, Rheinwald G (eds) Birds in European cities. Ginster, Germany, (2005) 127-152.

[10] R. Mulsow. The birdlife of Hamburg. Hamburger Avifauna Beitrage Special Edition IOC Hamburg, (2006) 45-76.

[11] Bird life International. Passer domesticus. In: IUCN 2008. 2008 IUCN Red list of threatened species. < www.iucnredlist.org $>$ (2008).

[12] L.M. Shaw, D. Chamberlain, and Evans, M. The House Sparrow (Passer domesticus) in urban areas: reviewing a possible link between post-decline distribution and human socioeconomic status. Journal of Ornithology, 149 (2008) 293-299.

[13] I. Newton, I. The recent declines of farmland bird population in Britain: an appraisal of causal factors and conservation factors. Ibis 146 (2004) 579-600.

[14] J.D. Summers-Smith. The decline of the House Sparrow: a review. British Birds, 96 (2003) 439-446.

[15] T.R. Anderson. Biology of the ubiquitous House Sparrow. Oxford University Press, Oxford (2006).

[16] S. Rajashekhar, and Venkatesha, M.G. Occurrence of House Sparrow, passer domesticus indicus in and around Bangalore. Current Science. 94 (2008) 446-449.

[17] A. Nath, A. Kalaimani, Debahutee, R. A note on House Sparrows of Thengumahada, Nilgiris. Newsletter for Birdwatchers, (4) (2012) 52. 
[18] B. Laxmi Narayana, V. Vasudeva Rao, M. Sandeep, G. Surender, and Ramaligeswara Rao. A.V.L.N. A preliminary survey of House Sparrow (Passer domesticus) in Ramakrishna Beach Road, Vishakhapatnam (Vizag), Andhra Pradesh. International Letters of Natural Sciences, 4 (2015) 1-6.

[19] C.W. Neu, C.R. Byres, and Peek, J.M. A technique for analysis of utilizationavailability data. Journal of Wildlife Management, 38(3) (1974) 541-545.

[20] A. Balmori, and Hallberg, O. The urban decline of the House Sparrow (Passer domesticus): a possible link with electromagnetic radiation. Electromagnetic Biology and Medicine, 26 (2007) 141-151.

[21] C.R. Byres, R.K. Steinhorst, and Krausman, P.R. 1984. Clarification of a technique for analysis of utilization-availability data. Journal of Wildlife Management, 48(3) (1984) 10501053.

[22] E.P. Odum, Fundamentals of Ecology. W.B. Saunders Co., Philadelphia (1971).

[23] H.Q.P. Crick, and Siriwardena. G.M. National trends in the breeding performance of House Sparrows Passer domesticus. In: Crick HQP, Robinson RA, Appleton GF, Clark NA, Rickard $A D$ (eds) Investigation into the causes of decline of starlings and house sparrows in Great Britain. BTO research report 290, DEFRA, Bristol. Available from:

http:/www.defra.gov.uk/wildlifecountryside/ resprog/findings/sparrow/ (2002)/.

[24] M.J. Raven, and Noble, D.G. The breeding bird survey 2005. Available from: http://www.bto.org/bbs/results/bbsreport.htm (2006). 